$\xi_{p}$

\title{
Greenhouse Gas (GHG) Emission Estimation from Cropland Remaining Cropland in AFOLU Sector for Various Districts in Sarawak
}

\author{
E. K. Peng ${ }^{1}$, M. A. Malek ${ }^{2}$, N. Azimah Bahrum ${ }^{3}$, C. S. Tan ${ }^{4}$ \\ ${ }^{I}$ Department of Civil Engineering, Universiti Tenaga Nasional, Malaysia \\ ${ }^{2}$ Institute of Energy Policy Research (IEPRe), Universiti Tenaga Nasional, Malaysia \\ *Corresponding author E-mail: pengek@gmail.com
}

\begin{abstract}
Greenhouse gases (GHG) exist in the world and lead to more heat being trapped. The study belongs to part of initiatives to establish GHG emission from Agricultural Forest Land Use (AFOLU) at Sarawak, Malaysia. The study implements Tier 1 methodology of 2006 IPCC (Intergovernmental Panel on Climate Change) Guidelines to estimate carbon dioxide $\left(\mathrm{CO}_{2}\right)$ emissions from cropland remaining cropland in Sarawak, in which uncertainty analyses are included. The study aids in establishing the quantity as well as trending of $\mathrm{CO}_{2}$ emissions from crops such as fruit trees, cocoa, pepper, rubber and palm oil cultivated in non-urban and non-rural areas of Sarawak from year of 2008 to 2012. Based on this study, it is found that Miri is the highest $\mathrm{CO}_{2}$ emitter from palm oil as compared to other districts with total amount of $681.55 \mathrm{kt} \mathrm{C} /$ year. It is also found that $\mathrm{CO}_{2}$ emission from crops cultivated in Limbang (non-urban) is the lowest with total values of $35.84 \mathrm{kt}$ C/year, $16.16 \mathrm{kt} \mathrm{C} /$ year, $0.13 \mathrm{kt} \mathrm{C} /$ year and $5.08 \mathrm{kt} \mathrm{C} /$ year for palm oil, rubber, pepper and fruit trees re spectively. Generally, results obtained from this study showed that at most districts in Sarawak, palm oil plantations produce the highest $\mathrm{CO}_{2}$ emission demonstrating increasing trend through-out the study duration, while the rubber plantations ranked second. Estimated emission values of $\mathrm{CO}_{2}$ can be used for planning and mitigation purposes at various level of confidence.
\end{abstract}

Keywords: 2006 IPCC Guidelines; carbon dioxide $\left(\mathrm{CO}_{2}\right)$; cropland remaining cropland; Greenhouse gas (GHG); Sarawak.

\section{Introduction}

Sarawak is one of the states in Malaysia, situated near to the equator. There are altogether six districts in the state namely Kuching, Miri, Sibu, Limbang, Sri Aman and Betong. In Sarawak, global population increase has shifted the land use practices towards agriculture. Among the major crops cultivated on agricultural land in Sarawak are palm oil, rubber, pepper, cocoa and fruit trees.

Sarawak has become one of the global hotspots on forest loss and degradation. As stated in the country's Second National Communication to UNFCCC (Ministry of Natural Resources and Environment Malaysia, MNRE 2015), Greenhouse Gas (GHG) emission from Land Use, Land Use Change and Forestry (LULUCF) sector is $13 \%$. Zomer et al., (2016) reported that expansion of cropland is occurring in the tropics in which approximately $80 \%$ of the expansion is substituting forests.

Bryan et al., (2013) also discovered nearly $80 \%$ of land surface in Sarawak is affected by clearing operations and high-impact logging for oil palm and other industries leading to carbon stocks emission. Simultaneously, limited data availability can affect its accuracy (West et al., 2010).

Estimation of GHGs emitted at different countries has recently gained global attention, including developing country such as Malaysia. Even though Malaysia is not included in the list of countries in Annex I of Kyoto Protocol (KP), Malaysia has taken active initiatives to reduce its GHG emission under the KP program (Hosseini et al., 2013). The KP program includes at least
$20 \%$ of Malaysia government procurement going green by year 2020 as outlined in the $11^{\text {th }}$ Malaysia Plan (The Sun Daily, 2015).

Since Malaysia is categorised as non-Annex I member, Malaysia do not have to decrease emissions of GHG. However, in year 2009, Prime Minister of Malaysia reported a voluntary goal of $40 \%$ decrement of carbon dioxide $\left(\mathrm{CO}_{2}\right)$ intensity from Malaysian GDP by year 2020 based on year 2005 baseline, which is conditioned to technology and financial support from developed countries. This initiative further demonstrated Malaysia's willingness to address its GHG emissions in order to attain sustainable development. Therefore, this study was initiated to reinforce Malaysia's pledge on reduction of its $\mathrm{CO}_{2}$ emission specifically for the state of Sarawak.

To the best of our knowledge, this paper is among the first papers to utilize 2006 IPCC Guidelines for computing change in biomass carbon stocks. In this study, estimations on change of biomass carbon stocks for crops cultivated in study area of Sarawak were conducted, due to the reason that carbon dioxide constituted $75.1 \%$ as compared to methane $(23.5 \%)$ and nitrous oxide $(1.3 \%)$ in Malaysia for the year 2000 (Malaysia's Ministry of Natural Resources and Environment, MNRE, 2011).

\section{Crop Cultivations of Sarawak}

The IPCC created six primary land-use categories particularly settlements, wetlands, grassland, cropland, forest land and other lands. These categories permit tracing of every land-use transfor- 
mations that may happen between intervals of time. For example, a piece of cropped land remains as a piece of cropped land during a given time interval. Hence the term cropland remaining cropland is introduced. The cropland category included cropped land. The ensuing section proved that crop cultivations are major source of carbon emission in Sarawak. The percentage of area is presented in Figure 1. Based on Sarawak Agriculture Statistics year 2013, the total land use area is recorded at 12 million hectares with crop showed $32.1 \%$ or approximately one-third of total land area in Sarawak.

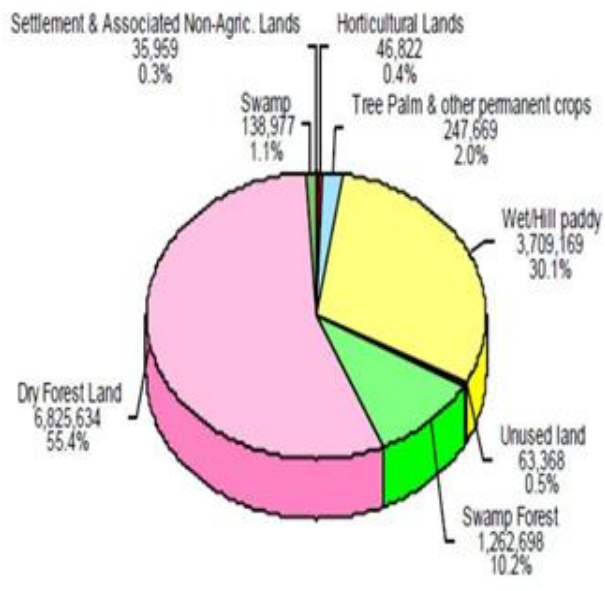

Fig. 1: Area and land use types in Sarawak. Source: Planning Metric Measurement Land Use Map, Sarawak Agriculture Statistics 2013.

Planted areas of crops in Sarawak are illustrated in Table 1. Crops such as cocoa, pepper and rubber are experiencing major and minor fluctuations of areas throughout the years. Variations in areas for these crops are determined by global and local commodity prices, market demand, local weather conditions such as flood and drought as well as insect attacks. On the other hand, oil palm cultivation area exhibited incremental trend with gaining momentum from year 2008 to 2012 .

Table 1: Changes in Planted Area of Crops (ha)

\begin{tabular}{|c|c|c|c|c|c|}
\hline Year & Cocoa & Pepper & Paddy & Rubber & Palm Oil \\
\hline 2008 & 5521 & 11,298 & 115,944 & 157,147 & 744,371 \\
\hline 2009 & 6336 & 10,889 & 118,998 & 159,010 & 839,750 \\
\hline 2010 & 7126 & 14,056 & 121,921 & 161,091 & 919,419 \\
\hline 2011 & 6775 & 14,518 & 127,112 & 158,853 & $1,021,587$ \\
\hline 2012 & 7263 & 14,603 & 129,040 & 158,025 & $1,076,238$ \\
\hline
\end{tabular}

\section{Method of Estimating Change in Biomass Carbon Stocks}

The calculations used are from Intergovernmental Panel on Climate Change (IPCC) Guidelines for National Greenhouse Gas Inventories. Since IPCC Guidelines stressed on the importance of using only official published data, the origin of raw data used in this study are officially provided by Chief Minister's Department and State Planning Unit of Sarawak with publication of Sarawak Facts and Figures year 2008 till 2012. A flowchart illustrating the flow of research work are presented in Figure 2.

This study aims to assess the changes in $\mathrm{CO}_{2}$ emission from biomass change of major crops cultivated in areas of cropland remaining cropland in Sarawak. The major crops investigated are palm oil, rubber, pepper, cocoa and fruit trees. From Figure 2, the first step would be to obtain each crop's cultivation area from each district. Then, 2006 IPCC Guidelines are referred and change of biomass carbon stocks can be quantified by using the provided formula in the guidelines. According to (Eggleston et al. 2006), three general methodologies existed to evaluate emissions of GHG known as "Tiers" ranging from 1 to 3 . Increasing tier represent higher level of information and complexity needed. Tier 1 method which is employed in this study is intended to be the least complex in which parameters such as emission and stock change factors are given by (Eggleston et al. 2006).

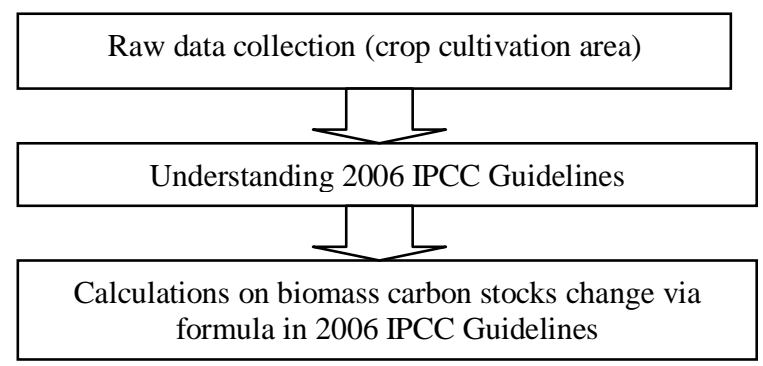

Fig. 2: Flowchart illustrating flow of research work

\subsection{Yearly Change in carbon Stocks of Biomass, $\Delta C_{B}$ (Tons $\mathrm{C} \mathrm{yr}^{-1}$ )}

Tier 1 methodology is as shown in Equation 1.

$\Delta C_{B}=\Delta C_{G}-\Delta C_{L}$

Definition 1: $\Delta C_{B}$ : yearly change in carbon stocks in biomass, tonnes $C \mathrm{yr}^{-1} ; \Delta C_{G}$ : yearly gain in carbon stocks, tonnes $C \mathrm{yr}^{-1}$; $\Delta C_{L}$ : annual loss in carbon stocks, tonnes $C y r^{-1}$.

In this study, it is assumed that $10 \%$ of crops cultivation areas are subjected to harvesting. Based on Tier 1 methodology, default factors presented in Table 2 were applied. According to the Biennial Update Report to UNFCCC (MNRE, 2015), the emission from cropland remaining cropland only include change in carbon stocks of biomass on all crops of interest.

Table 2: Default Coefficients for Above-Ground Woody Biomass and Harvest Cycles in Cropping Systems Containing Perennial Species (Eggleston et al., 2006)

\begin{tabular}{|c|c|c|c|} 
Climate region & $\begin{array}{c}\text { Biomass accu- } \\
\text { mulation rate } \\
(\mathrm{G})(\text { tonnes C } \\
\left.\mathrm{ha}^{-1} \mathrm{yr}^{-1}\right)\end{array}$ & $\begin{array}{c}\text { Biomass carbon } \\
\text { loss (L) (tonnes } \\
\left.\mathrm{C} \mathrm{ha}^{-1} \mathrm{yr}^{-1}\right)\end{array}$ & Error range $^{1}$ \\
\hline Tropical, moist & 2.6 & 21 & $\pm 75 \%$ \\
\hline
\end{tabular}

Note: Values are derived from the literature survey and synthesis.

${ }^{1}$ Represents a nominal estimate of error, as a percentage of the mean.

\subsection{Uncertainty Analyses}

In this study, uncertainty analyses is assumed to employ statistical normal distribution with $95 \%$ confidence interval (CI) of $30 \%$ from Mean of Tier 1. It is based on Equation 2.

$U_{\text {total }}=U_{1}^{2}+U_{2}^{2}+\ldots .+U_{n}^{2}$

Definition 2: $U_{\text {total }}=$ Product of the amounts (half the 95 percent confidence interval divided by the total and expressed as a percentage); $U_{l}=$ Percentage uncertainties related with each of the amounts.

\section{Results and Discussion}

The annual $\mathrm{CO}_{2}$ emissions due to change in carbon stocks of biomass for crops from urban and non-urban areas of Sarawak are presented by Figure 2 to 4 and Figure 5 to 7 respectively. 


\subsection{Kuching}

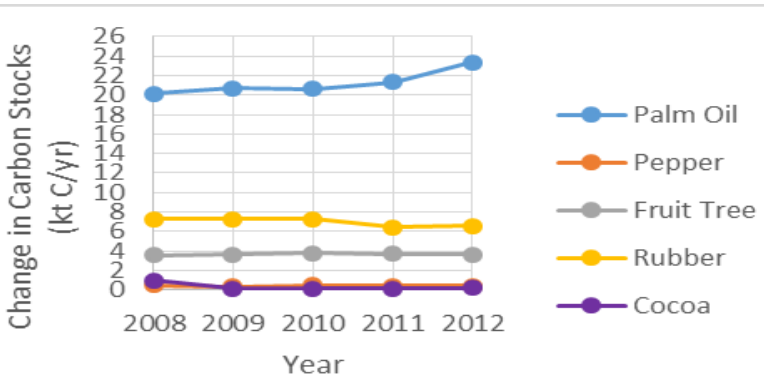

Fig. 2: Change in biomass carbon stock from cropland remaining cropland of Kuching.

Based on Figure 2, palm oil plantations are the highest cropland that emitted $\mathrm{CO}_{2}$ from $20.11 \mathrm{kt} \mathrm{C} / \mathrm{yr}$ to $23.36 \mathrm{kt} \mathrm{C} / \mathrm{yr}$ at year 2008 to 2012. As compared to other crops in Kuching, palm oil plantations ranked first, while rubber plantations ranked second. For emission from pepper and paddy, the emission values fluctuate between $0.35 \mathrm{kt} \mathrm{C} / \mathrm{yr}$ to $0.47 \mathrm{kt} \mathrm{C} / \mathrm{yr}$ and $1.22 \mathrm{kt} \mathrm{C} / \mathrm{yr}$ to $1.60 \mathrm{kt}$ $\mathrm{C} / \mathrm{yr}$ respectively. Meanwhile, it was discovered that emissions from fruit trees cultivation in Kuching are the highest among all other districts. Cocoa yielded the least ranging from $0.15 \mathrm{kt} \mathrm{C} / \mathrm{yr}$ to $0.17 \mathrm{kt} \mathrm{C} / \mathrm{yr}$. This is because cocoa cultivation area are changed to other crops such as palm oil that returned higher yield contrast to other crops, which agrees with discoveries of (Latif et al., 2014).

\subsection{Miri}

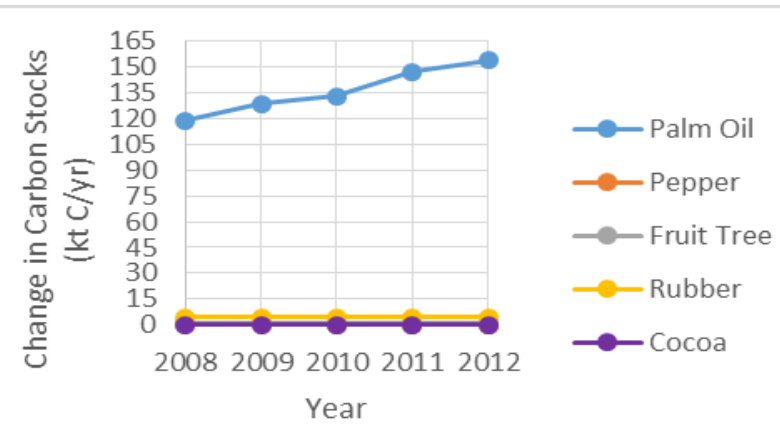

Fig. 3: Change in biomass carbon stock from cropland remaining cropland of Miri.

Figure 3 shows top $\mathrm{CO}_{2}$ emitter which is palm oil. Agus et al. (2013) discovered in Malaysia, between year 1990 and 2010, huge areas of existing agricultural land and other types of plantation estates were changed to palm oil. This explains the reason for the abrupt change in biomass carbon stock of oil palm all the way from 2008 to 2012. Cocoa cultivations demonstrated minor changes at 0 to $0.01 \mathrm{kt} \mathrm{C} / \mathrm{yr}$.

\subsection{Sibu}

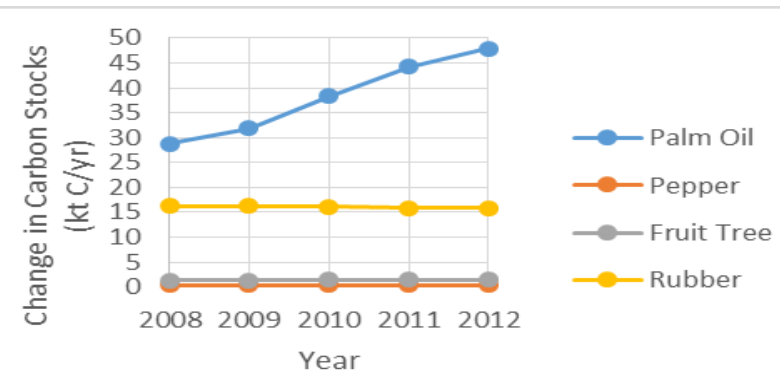

Fig. 4: Change in biomass carbon stock from cropland remaining cropland of Sibu.
From Figure 4, palm oil plantations again ranked first. It was also found that rubber plantations in Sibu, demonstrated the highest value of annual $\mathrm{CO}_{2}$ emission among other six (6) districts in Sarawak. Figure 4 shows similar emission trend for all crops except for palm oil which has a significant increasing trend from year 2008 to 2012.

\subsection{Limbang}

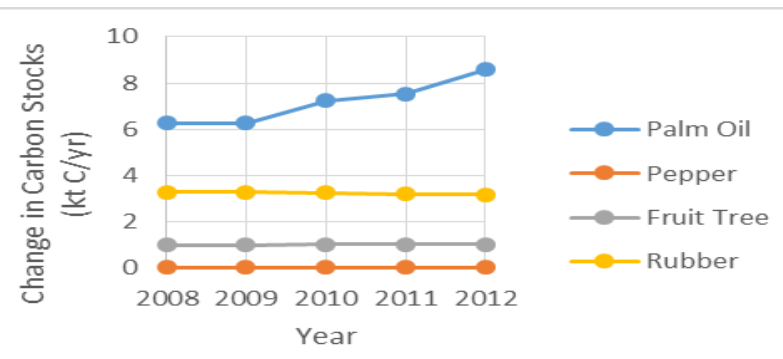

Fig. 5: Change in biomass carbon stock from cropland remaining cropland of Limbang.

Based on findings obtained in this study, all the crops cultivated in Limbang released the least $\mathrm{CO}_{2}$ emission, as presented in Figure 5. Cocoa is not cultivated in Limbang. Besides that, it was also found that emission from other crops showed similar decreasing trend on the annual carbon stocks in biomass from year 2008 to year 2012.

\subsection{Sri Aman}

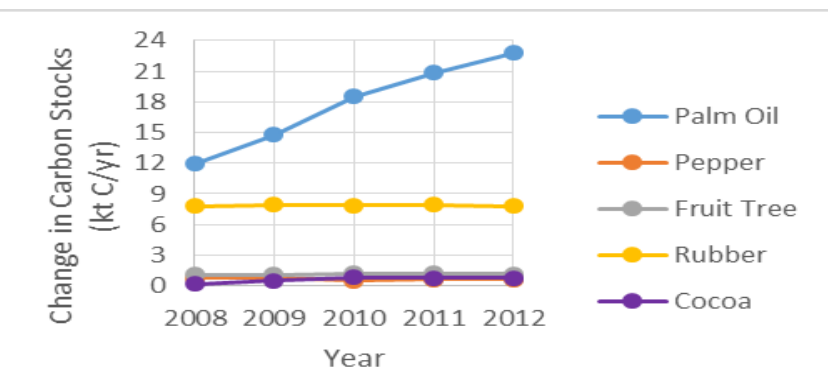

Fig. 6: Change in biomass carbon stock from cropland remaining cropland of Sri Aman.

As shown in Figure 6, palm oil plantations occupied 54\% from the total carbon stocks of biomass in Sri Aman. In addition, paddy and cocoa cultivations in Sri Aman are found to rank first in emission as compared to emission from similar crops at other districts. Adhya et al., (2014) suggested to intrude on flooding in rice paddies, leading to reduction in populations of methane-producing bacteria. There is an insignificant change in $\mathrm{CO}_{2}$ emission from pepper and fruit trees at the range of $0.53 \mathrm{kt} \mathrm{C} / \mathrm{yr}$ to $0.75 \mathrm{kt} \mathrm{C} / \mathrm{yr}$ and $1.08 \mathrm{kt} \mathrm{C} / \mathrm{yr}$ to $1.21 \mathrm{kt} \mathrm{C/yr}$ respectively.

\subsection{Betong}

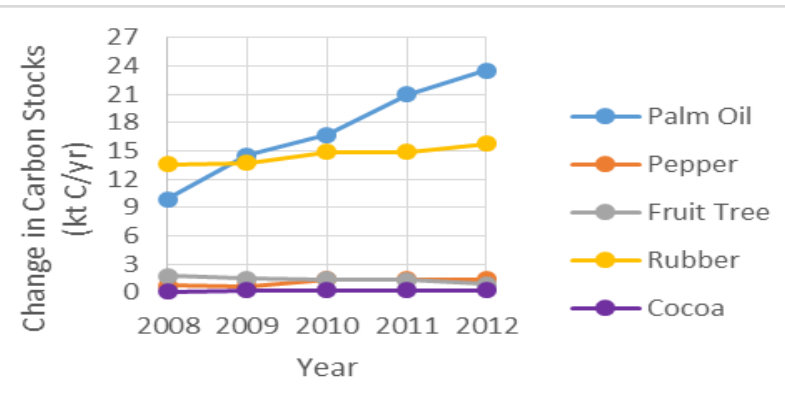

Fig. 7: Change in biomass carbon stock from cropland remaining cropland of Betong. 
Figure 7 presents all crops, except for palm oil and rubber, exhibited similar trends between years 2008 till 2012. Pepper cultivated in this region showed a summation of $5.42 \mathrm{kt} \mathrm{C} / \mathrm{yr}$ being discharged from year 2008 to 2012 because of rise of pepper's prices such that price of creamy white pepper is currently traded around RM 40,000 per tonne while black pepper RM 19,000 per tonne (Pepper Commodity Price, 2017). (Wong, 2016) expressed Sarawak remain Malaysia's key pepper generation state which contributed over $95 \%$ of the nation's yield. Malaysia is likewise the world's fifth producer among International Pepper Community (IPC) members with yield of 28,000 tonnes in 2015 .

\subsection{Uncertainty Analyses}

Based on the statistical calculations performed in this study, the percentage of uncertainty analysis on raw data provided for croplands from Kuching, Miri, Sibu, Limbang, Sri Aman and Betong are found to be at $4.84 \%, 2.94 \%, 10.23 \%, 4.59 \%, 10.28 \%$ and $14.81 \%$ respectively as summarized in Table 3 .

Table 3: Percentage for uncertainty analysis conducted on raw data

\begin{tabular}{|c|c|c|c|c|c|c|}
\hline & $\begin{array}{c}\text { Kuchin } \\
\mathrm{g}\end{array}$ & Miri & Sibu & $\begin{array}{c}\text { Lim- } \\
\text { bang }\end{array}$ & $\begin{array}{c}\text { Sri } \\
\text { Aman }\end{array}$ & Betong \\
\hline $\begin{array}{c}\text { Uncer- } \\
\text { tainty } \\
(\%)\end{array}$ & 4.84 & 2.94 & 10.23 & 4.59 & 10.28 & 14.81 \\
\hline
\end{tabular}

In short, since the uncertainty analyses conducted on raw data used in this study are found to be less than $50 \%$, therefore it can be concluded that estimation values carried out in this study are dependable.

\section{Conclusion and Recommendation}

This study examined the GHG emission estimation from croplands at various districts of Sarawak. It has proven that the carbon emitted depended heavily on type of planted crop. Finding shows change of biomass carbon stocks for palm oil plantations in Miri are the highest as compared to other districts in Sarawak at the range of $119 \mathrm{kt} \mathrm{C} / \mathrm{yr}$ to $154 \mathrm{kt} \mathrm{C/yr}$ between years 2008 till 2012 (Figure 3). Since Miri is found to experience the highest amount of $\mathrm{CO}_{2}$ emission from its crop cultivation, therefore there is an urgent need to further prioritise mitigation measures to control $\mathrm{CO}_{2}$ emission in Miri.

The yearly emission of $\mathrm{CO}_{2}$ from crop cultivation relies heavily on the area allocated for crop cultivation. In urban areas of Sarawak during the period of 2008 to 2012 , it is found that fruit trees contributed the highest $\mathrm{CO}_{2}$ emission in Kuching with values ranging from 3.54 to $3.74 \mathrm{kt} \mathrm{C/yr} \mathrm{(Figure} \mathrm{2).} \mathrm{While} \mathrm{the} \mathrm{highest} \mathrm{CO}_{2}$ emission was from rubber plantation in Sibu with values ranging from 15.79 to $16.28 \mathrm{kt} \mathrm{C/yr}$. Meanwhile for non-urban areas of Sarawak, the highest $\mathrm{CO}_{2}$ emission was from cocoa cultivated in Sri Aman with emission values of 0.15 to $0.80 \mathrm{kt} \mathrm{C} / \mathrm{yr}$ respectively. For pepper, its peak $\mathrm{CO}_{2}$ emission was from district of Betong with emission values ranges from 0.67 to $1.37 \mathrm{kt} \mathrm{C} / \mathrm{yr}$. Lastly, Limbang district emitted the lowest amount of $\mathrm{CO}_{2}$ emission as compared to the other six (6) districts in Sarawak.

In conclusion, results obtained in the study established the quantity of $\mathrm{CO}_{2}$ emission particularly in the districts of Sarawak that traps heat energy from the sun. Excessive amount of this gas can lead to global warming. Results obtained from this study can be treated as one of the initiatives to support the voluntary pledge made by Malaysia's Prime Minister at 2008 Rio Summit in reducing its emission by $40 \%$ of its Gross Domestic Product (GDP) by year 2020

\section{Acknowledgement}

The authors wish to thank State Planning Unit, Chief Minister's Department and Department of Agricultural Sarawak for access to published data.

\section{References}

[1] T. K. Adhya, B. Linquist, T. Searchinger, R. Wassmann, X. Yan, Wetting and drying: reducing greenhouse gas emissions and saving water from rice production, World Resources Institute, (2014), 1-28.

[2] F. Agus, P. Gunarso, B. H. Sahardjo, N. Harris, M. Noordwijk, T. J. Killen, Historical $\mathrm{CO}_{2}$ emissions from land use and land use change from the oil palm industry in Indonesia, Malaysia and Papua New Guinea, Roundtable on Sustainable Palm Oil, Switzerland, 2013.

[3] J. E. Bryan, P. L. Shearman, G. P. Asner, D. E. Knapp, B. Lokes, Extreme differences in forest degradation in Borneo: comparing practices in Sarawak, Sabah, and Brunei, PLoS ONE, 8, (2013), 1-7.

[4] S. Eggleston, L. Buendia, K. Miwa, T. Ngara, K. Tanabe, IPCC Guidelines for National Greenhouse Gas Inventories, Vol, 4, Institute for Global Environmental Strategies, Hayama, Japan, 2006.

[5] S. E. Hosseini, M. A. Wahid, N. Aghili, The scenario of greenhouse gases reduction in Malaysia, Renewable and Sustainable Energy Reviews, 28, (2013), 400-409.

[6] J. T. Houghton, Y. Ding, D. J. Griggs, M. Noguer, P. J. Linden, X. Dai, K. Maskell, C. A. Johnson, Climate change 2001: the scientific basis. Contribution of Working Group I to the Third Assessment Report of the Intergovernmental Panel on Climate Change, Cambridge University Press, United Kingdom and New York, 2001.

[7] A. Latif, H. Ismail, P. Elizabeth, Carbon stocks and emissions of Malaysian forests, Forest Research Institute Malaysia, Malaysia, 2014.

[8] Malaysia's Ministry of Natural Resources and Environment (MNRE), Malaysia's Second National Communication (NC2) to the UNFCCC, Ministry of Natural Resources and Environment, Malaysia, 2011.

[9] Malaysia's Ministry of Natural Resources and Environment (MNRE), Biennial Update Report (BUR) to the UNFCCC, Ministry of Natural Resources and Environment, Malaysia, 2015.

[10] Official Portal of Malaysian Pepper Board. Pepper commodity price Jan to Dec 2017. http://www.mpb.gov.my/mpb/index.php/my/ Revised Dec 2017. Accessed March 3, 2018.

[11] Sarawak's Department of Agriculture, Sarawak Agriculture Statistics, Department of Agriculture, Malaysia, 2013.

[12] The Sun Daily. 11MP: 20\% Govt green procurement by 2020 target http://www.thesundaily.my/news/1426490. Revised May 2015. Accessed June 15, 2018

[13] P. C. West, H. K. Gibbs, C. Monfreda, J. Wagner, B. C. Barford, S R. Carpenter, J. A. Foley, Trading carbon for food: global comparison of carbon stocks vs. crop yields on agricultural land, PNAS, 107, 46, (2010), 19645-19648.

[14] Wong, J. Lucrative pepper farming. http://www.thestar.com.my/metro/community/2016/06/08/lucrative -pepper-farming-prices-soar-as-more-people-use-the-spice-in-foodprocessing-and-manufacturi/. Revised Jun 2016. Accessed Dec 10, 2017.

[15] R. J. Zomer, H. Neufeldt, J. Xu, A. Ahrends, D. Bossio, A. Trabucco, M. Noordwijk, M. Wang, Global tree cover and biomass carbon on agricultural land: the contribution of agroforestry to global and national carbon budgets, Scientific Reports, 6, (2016), 112 